\title{
Performance and ileal characteristics of finishing Broilers fed diets supplemented with prebiotics (Mannose and Lactose)
}

\author{
Oni, O. O. ${ }^{*}$, Idowu, O. M. O. ${ }^{2}$, Oso, A. $0^{2}$ and Ikeobi, C. O. N. ${ }^{3}$ \\ ${ }^{1}$ Department of Agricultural Education, Federal College of Education, Osiele, Abeokuta, Ogun State, Nigeria. \\ ${ }^{2}$ Department of Animal Nutrition, Federal University of Agriculture, Abeokuta, Ogun State, Nigeria. \\ ${ }^{3}$ Department of Animal Breeding and Genetics, Federal University of Agriculture, Abeokuta, Ogun State, Nigeria. \\ ${ }^{*}$ Corresponding author. Email: onioluwakemi873@gmail.com.
}

Copyright @ 2016 Oni et al. This article remains permanently open access under the terms of the Creative Commons Attribution License 4.0, which permits unrestricted use, distribution, and reproduction in any medium, provided the original work is properly cited.

Received 23rd June, 2016; Accepted 2nd August, 2016

\begin{abstract}
An experiment was conducted to evaluate the effect of prebiotics supplemented diets on performance characteristics and gut morphology of broiler chickens. The study involved 320 day-old Anak broiler chicks, used to assess the utilization of prebiotics [Mannose oligosaccharides (MOS) and Lactose oligosaccharides (LOS)] by broiler chicks. The chicks were alloted to eight treatment groups of 40 birds each and four replicates of 10 birds each in a $2 \times 4$ factorial arrangement. The additives (MOS and LOS) were added to the diets at four levels $(0,250,500$ and $750 \mathrm{ppm})$ per additive. The birds were fed for 56 days, after which data on feed intake, body weight gain, feed conversion ratio and ileal morphology were collected. The data was subjected to analysis of variance and significant means were separated using Duncan's Multiple Range Test. Results showed that final weight values significantly $(p<0.05)$ ranged from 1276.67 to $1503.38 \mathrm{~g}$. The ileum morphology of the finishers broilers showed that villi height, lamina propria depth, basal width and apical width were significantly $(p<0.05)$ influenced by prebiotic sources and levels. The villi height of $2250.00 \mu \mathrm{m}$ was highest at $500 \mathrm{ppm}$ MOS level of inclusion, while the least value of $538.30 \mu \mathrm{m}$ was obtained in birds fed $0 \mathrm{ppm}$ Lactose inclusion. It was therefore, concluded that, prebiotic MOS at 500ppm could be used in feed to obtain the better weight gain and FCR, with normal gut morphology of broiler chickens.
\end{abstract}

Key words: Broilers, ileal morphology, lactose oligosaccharide, mannan oligosaccharide, performance.

\section{INTRODUCTION}

Antibiotics have been used in agriculture to promote growth and welfare of animals for the past 80 years in the United States and other countries (Dibner and Richards, 2005). The long term and extensive use of antibiotics in human and veterinary medicine have resulted in selection of resistant bacterial strains. Resistance among gramnegative bacteria, like E. coli and Salmonella spp. has generated the strongest objection to antibiotic use (Gustafon and Bowen, 1997). As an illustration of many other surveys in the literature conducted to show antimicrobial resistance, Nayak and Kenney (2002) showed that $25 \%$ of the Salmonella isolates from turkey flocks in West Virginia were resistant to one or more antibiotics, including gentamycin, spectinomycin, streptomycin, tetracycline, tobramycin and trimethoprim. The European Union ban on the use of most of the subtherapeutic antibiotics in animal feed was based on the fears of antibiotic resistance being transferred via the food chain and proposed the precautionary principle since 1997 (Cervantes, 2005). Cervantes (2005) reported that, the ban of antibiotic feed additives has resulted to significant decrease of antibiotic resistance among bacteria isolated from raw meat products. Additionally, associated with the ban on feed-additive antibiotic was a rise in the incidence of colibacillosis and necrotic enteritis in poultry (Truscott and Alsheikhly, 1997; Ferket, 2003) 
and pigs (Casewell et al., 2003; Cervantes, 2005).

However, with the limitation of antibiotic growth promoters (AGPs), the consequent need for their total withdrawal becomes necessary. Hence, the need to find alternative feed supplements that have probiotic and prebiotic effects and promote growth of broiler chickens, thus achieving both enhanced performance and good health without the use of antibiotics. In order to find better alternatives to AGPs, research has focused on utilization of feed additives such as enzymes, probiotics, prebiotics, symbiotic products and even nutrient to enhance gut health and prevent or limit production losses due to enteric infections.

Prebiotics are dietary components that are not digested by the host, but they benefit the host by selectively stimulating the growth and/or activity of one or a limited number of bacteria in the gastro-intestinal tract (GIT), predominantly those that produce short chain fatty acids (SCFA). However, dietary supplementation of prebiotics has been shown to stimulate these unculturable bacteria in humans (Rastall et al., 2005), and pigs (Konstantinov et al., 2003).

Lactose is a major type of sugar found in milk and milk products, including human milk. It constitutes less than $80 \%$ of the solid in milk, in animals. Lactase and enzymes produced by the small intestine break down lactose so it can be absorbed into the blood stream. Lactose is one of the prebiotics and it functions by lowering the gut $\mathrm{pH}$ through lactic acid production, inhibiting/preventing colonization of pathogens, modifying metabolic activities of normal intestinal flora and stimulation of the immune system (Fons and Tuomo Karjalainen, 2000).

Mannan oligosaccharides are derived from yeast cell wall and work slightly differently from fructooligosaccharides. The major difference between fructooligosaccharides and mannan-oligosaccharides (MOS) is that MOS products do not selectively enrich for beneficial bacteria. The binding and removing of pathogens while stimulating the immune system are the primary mode of action for MOS products (Patterson and Burkholder, 2003). Therefore, this study was designed to evaluate the effects of prebiotic supplemented diets on performance and gut morphology of finishing broiler chickens.

\section{MATERIALS AND METHODS}

\section{Experimental site}

The experiment was carried out at the Poultry Unit of the Directorate of the University Farms (DUFARMS), Federal University of Agriculture, Abeokuta, Ogun State, Nigeria. It falls within the rainforest vegetation zone of SouthWestern Nigeria at latitude $7^{\circ} 13^{\prime} 49.46^{\prime \prime} \mathrm{N}$, longitude $3^{\circ} 26^{\circ}$ 11.98" $\mathrm{E}$ and altitude of 76 meters above sea level. The climate is humid with a mean annual rainfall of $1037 \mathrm{~mm}$. The annual mean temperature and humidity is $34.7^{\circ} \mathrm{C}$ and $82 \%$ respectively.

\section{Experimental diets}

A basal diet was formulated to conform to the nutrient requirements of broiler chickens in the Tropics according to NRC (1994) as shown in Table 1. Diets were prepared by adding Lactose oligosaccharide or Mannan oligosaccharide at $0,250,500$ and $750 \mathrm{ppm}$, and this gives a total of eight diets.

\section{Experimental birds, design and management}

A total of 320 day-old broiler chicks of commercial strain (Anak et al., 2000) were purchased from Nubreed Farms Ltd., Abeokuta, Ogun State, Nigeria. The birds were fed ad libitum on broiler starter for a period of 28 days (Table 1) and finisher diet (Table 2) from week 5 to 8 . They were allocated randomly to eight dietary treatment groups of 40 birds each. Each treatment was further divided into four replicate groups of ten birds each. The birds were assigned randomly to eight dietary treatments in a $2 \times 4$ factorial arrangement. Prebiotics (Lactose and Mannose) were included in a $2 \times 4$ factorial arrangement of 4 inclusion levels $(0,250,500$ and $750 \mathrm{ppm})$ and two prebiotic sources (Lactose and Manose). Fresh and clean water was supplied ad libitum. All the routine and occasional management practices were carried out as at when due using standard practice.

\section{Data collection}

Data were collected on growth indices such as: weight gain, feed intake and feed conversion ratio. Feed conversion ratio $(\mathrm{FCR})$ was calculated as the ratio $(\mathrm{kg} / \mathrm{kg})$ of average daily DM intake to average daily BW gain.

\section{Gut morphology of broiler chickens}

This analysis was carried out at the Veterinary Pathology Laboratory of Federal University of Agriculture, Abeokuta, Ogun State, Nigeria. At the end of the experiment (56 days), one bird per replicate was slaughtered. The small intestine (ileum, duodenum and jejunum) was excised immediately and fixed in formalin for the measurement of villus height $(\mathrm{VH})$, Apical width (AW), Lamina Propria Depth (LPD) and Basal width (BW). They were determined at a magnification of $\times 10$.

\section{Proximate analysis}

The proximate compositions of the diets were determined according to the methods described by AOAC (2000). 
Table 1. Gross composition of Experimental Diets to be fed to broiler chicks (0-4weeks) (g/kg).

\begin{tabular}{|c|c|c|c|c|c|c|c|c|}
\hline \multirow{2}{*}{ Ingredients } & \multicolumn{4}{|c|}{ Lactose } & \multicolumn{4}{|c|}{ Mannose } \\
\hline & 0 ppm & 250 ppm & 500 ppm & 750 ppm & 0 ppm & 250 ppm & 500 ppm & 750 ppm \\
\hline Maize & 460.00 & 460.00 & 460.00 & 460.00 & 460.00 & 460.00 & 460.00 & 460.00 \\
\hline Soyabean meal & 330.00 & 330.00 & 330.00 & 330.00 & 330.00 & 330.00 & 330.00 & 330.00 \\
\hline Fish meal & 30.00 & 30.00 & 30.00 & 30.00 & 30.00 & 30.00 & 30.00 & 30.00 \\
\hline Wheat offal & 100.00 & 100.00 & 100.00 & 100.00 & 100.00 & 100.00 & 100.00 & 100.00 \\
\hline LOS & + & ++ & +++ & ++++ & - & - & - & - \\
\hline Bone meal & 20.00 & 20.00 & 20.00 & 20.00 & 20.00 & 20.00 & 20.00 & 20.00 \\
\hline Salt & 2.50 & 2.50 & 2.50 & 2.50 & 2.50 & 2.50 & 2.50 & 2.50 \\
\hline Premix & 2.50 & 2.50 & 2.50 & 2.50 & 2.50 & 2.50 & 2.50 & 2.50 \\
\hline Methionine & 3.00 & 3.00 & 3.00 & 3.00 & 3.00 & 3.00 & 3.00 & 3.00 \\
\hline M.E (Mjg-1) & $2,743.30$ & $2,743.30$ & $2,743.30$ & $2,743.30$ & $2,743.30$ & $2,743.30$ & $2,743.30$ & $2,743.30$ \\
\hline Crude Protein & 22.0 & 22.0 & 22.0 & 22.0 & 22.0 & 22.0 & 22.0 & 22.0 \\
\hline Crude Fibre & 3.78 & 3.78 & 3.78 & 3.78 & 3.78 & 3.78 & 3.78 & 3.78 \\
\hline Ether Extract & 3.69 & 3.69 & 3.69 & 3.69 & 3.69 & 3.69 & 3.69 & 3.69 \\
\hline $\mathrm{Ca}(\%)$ & 1.78 & 1.78 & 1.78 & 1.78 & 1.78 & 1.78 & 1.78 & 1.78 \\
\hline AV Phos (\%) & 0.45 & 0.45 & 0.45 & 0.45 & 0.45 & 0.45 & 0.45 & 0.45 \\
\hline Lysine (\%) & 1.30 & 1.30 & 1.30 & 1.30 & 1.30 & 1.30 & 1.30 & 1.30 \\
\hline Methionine (\%) & 0.65 & 0.65 & 0.65 & 0.65 & 0.65 & 0.65 & 0.65 & 0.65 \\
\hline
\end{tabular}

Vitamin and mineral premix contained the following per kg diet: Vit; 4,000,000lu, Vit D:80000, VitB12:25mg, Niacin:6000mg, Vit E40000, Vit k3 $800 \mathrm{mg}$, VitB3 1000mg, Vit B26000mg, Vit B6: $5000 \mathrm{mg}$ panthotenic Acid: 20000, Folics Acid: $200 \mathrm{mg}$, Biotine: $8 \mathrm{mg}$, Maganese:30000, Iron: 8000 mg, Zinc: $2000 \mathrm{mg}$, Copper: nill, Cobalt: $80 \mathrm{mg}$, lodine: $400 \mathrm{mg}$, Selenium: 40mg, Choline: $80000 \mathrm{mg} .{ }^{* *}$ Lactose: 0 ppmL.S, +: $250 \mathrm{ppm}$ L.S ++: 500 ppm L.S, +++:750 ppm L.S, ${ }^{* *}$ Mannose: 0 ppmB.C, +: 250 ppmB.C, ++: 500 ppmB.C, +++: 750 ppmB.C.

\section{Statistical analysis}

All data collected were analysed using the General Linear Model of SAS (1999), and means were subjected to analysis of variance (ANOVA) in a $2 \times 4$ factorial design (SAS, 1999), while significant $(P<0.05)$ means were compared using Duncan's Multiple Range Test (Duncan, 1955).

\section{RESULT AND DISCUSSION}

The interaction effect for prebiotic sources and levels on the performance of broiler finisher is shown in Table 3.

Total feed intake and FCR were affected $(\mathrm{P}<0.05)$ by sources of prebiotic supplemented diets. All birds fed with lactose and $500 \mathrm{ppm}$ mannose had higher $(\mathrm{P}<0.05)$ values of final live weight and total weight gain. Improved $(P<0.05)$ feed conversion ratio was observed on birds fed with mannose-supplemented diet at $500 \mathrm{ppm}$ while other dietary treatments recorded lower values. This was in line with findings of Hooge (2004) who concluded that, birds fed with MOS showed improved growth performance and feed conversion ratio compared to birds fed diets containing antibiotic growth promoters. Also, Blake et al. (2006) indicated that, the addition of MOS to broiler diets showed a positive influence in promoting body weight gain with values far above birds fed control diet. Higher final live weight, weight gain and improved FCR recorded for broilers fed 500 ppm mannan oligossacharides (MOS) suggested the superiority of MOS over lactose (LOS) in supporting growth and feed utilization.

The result of the interaction effect of prebiotic sources and levels on the ileum morphology (Table 4), showed that villi height, lamina propia depth, basal width and apical width of broiler finishers were influenced $(P<0.05)$ by prebiotic sources and levels. The villi height $(P<0.05)$ was highest at $500 \mathrm{ppm}$ mannose level of inclusion (2250.00 um), while it was least (583.30 um) at $750 \mathrm{ppm}$ mannose inclusion. Higher $(P<0.05)$ values in $B W$ of birds fed $500 \mathrm{ppm}$ mannose was recorded, and the least 
Table 2. Gross composition of experimental diets fed to broiler finishers (4-8 weeks) $(\mathrm{g} / \mathrm{kg})$.

\begin{tabular}{|c|c|c|c|c|c|c|c|c|}
\hline \multirow[b]{2}{*}{ Ingredients } & \multicolumn{4}{|c|}{ Lactose } & \multicolumn{4}{|c|}{ Mannose } \\
\hline & $0 \mathrm{ppm}$ & 250 ppm & 500 ppm & 750 ppm & $0 \mathrm{ppm}$ & 250 ppm & 500 ppm & 750 ppm \\
\hline Maize & 470.00 & 470.00 & 470.00 & 470.00 & 470.00 & 470.00 & 470.00 & 470.00 \\
\hline Soyabean meal & 260.00 & 260.00 & 260.00 & 260.00 & 260.00 & 260.00 & 260.00 & 260.00 \\
\hline Vegetable oil & 45.00 & 45.00 & 45.00 & 45.00 & 45.00 & 45.00 & 45.00 & 45.00 \\
\hline Fish meal (72\%) & 15.00 & 15.00 & 15.00 & 15.00 & 15.00 & 15.00 & 15.00 & 15.00 \\
\hline Wheat offal & 150.00 & 150.00 & 150.00 & 150.00 & 150.00 & 150.00 & 150.00 & 150.00 \\
\hline Bone meal & 20.00 & 20.00 & 20.00 & 20.00 & 20.00 & 20.00 & 20.00 & 20.00 \\
\hline Oyster shell & 30.00 & 30.00 & 30.00 & 30.00 & 30.00 & 30.00 & 30.00 & 30.00 \\
\hline Salt & 2.50 & 2.50 & 2.50 & 2.50 & 2.50 & 2.50 & 2.50 & 2.50 \\
\hline Methionine & 2.50 & 2.50 & 2.50 & 2.50 & 2.50 & 2.50 & 2.50 & 2.50 \\
\hline Lysine & 2.50 & 2.50 & 2.50 & 2.50 & 2.50 & 2.50 & 2.50 & 2.50 \\
\hline *Premix & 2.50 & 2.50 & 2.50 & 2.50 & 2.50 & 2.50 & 2.50 & 2.50 \\
\hline **Lactose & & + & ++ & +++ & - & - & - & - \\
\hline ***Mannose & - & - & - & - & - & + & ++ & +++ \\
\hline Total & 1000 & 1000 & 1000 & 1000 & 1000 & 1000 & 1000 & 1000 \\
\hline
\end{tabular}

\section{Calculated Analysis}

\begin{tabular}{lcccccccc} 
ME $\left(\mathrm{MJKg}^{-1}\right)$ & 12.80 & 12.80 & 12.80 & 12.80 & 12.80 & 12.80 & 12.80 & 12.80 \\
Crude Fibre & 3.88 & 3.88 & 3.88 & 3.88 & 3.88 & 3.88 & 3.88 & 3.88 \\
Crude Protein & 20.00 & 20.00 & 20.00 & 20.00 & 20.00 & 20.00 & 20.00 & 20.00 \\
Fat & 3.51 & 3.51 & 3.51 & 3.59 & 3.51 & 3.51 & 3.51 & 3.51 \\
Ca (\%) & 1.47 & 1.47 & 1.47 & 1.47 & 1.47 & 1.47 & 1.47 & 1.47 \\
AV phos (\%) & 0.45 & 0.45 & 0.45 & 0.45 & 0.45 & 0.45 & 0.45 & 0.45 \\
Lysine (\%) & 1.25 & 1.25 & 1.25 & 1.25 & 1.25 & 1.25 & 1.25 & 1.25 \\
Methionine (\%) & 0.6 & 0.6 & 0.6 & 0.6 & 0.6 & 0.6 & 0.6 & 0.6 \\
\hline
\end{tabular}

Vitamin and mineral premix contained the following per kg diet: Vit;4,000,000lu, Vit D:80000, VitB12:25mg, Niacin:6000mg, Vit E40000, Vit k3 $800 \mathrm{mg}$, VitB3 1000mg, Vit B26000mg, Vit B6:5000mg panthotenic Acid:20000, Folics Acid:200mg, Biotine 8mg, Maganese:30000, Iron8000mg, Zinc:2000mg, Copper: nill, Cobalt: 80mg, lodine:400mg, Selenium:40mg, Choline:80000mg. ** Lactose: -: OppmL.S, +:250ppm L.S $++: 500$ ppm L.S +++:750ppm L.S, ${ }^{* \star *}$ Mannose: $-:$ :0ppmB.C, $+: 250 p p m B . C,++: 500 p p m B . C,+++: 750 p p m B . C$.

Table 3. Interaction effect of prebiotic sources and prebiotic levels of inclusion on the performance characteristics of finishing broilers.

\begin{tabular}{|c|c|c|c|c|c|c|c|c|c|}
\hline \multirow{2}{*}{ Parameters } & \multicolumn{4}{|c|}{ Lactose } & \multicolumn{4}{|c|}{ Mannose } & \multirow{2}{*}{ SEM } \\
\hline & $0 \mathrm{ppm}$ & $250 \mathrm{ppm}$ & 500 ppm & 750 ppm & $0 \mathrm{ppm}$ & 250 ppm & 500 ppm & 7500 ppm & \\
\hline Average initial weight (g) & 666.67 & 640.0 & 660.0 & 640.0 & 660.0 & 660.0 & 680.0 & 600.0 & 19.33 \\
\hline Average final weight $(\mathrm{g})$ & $1370.0^{\mathrm{ab}}$ & $1356.67^{\mathrm{ab}}$ & $1383.33^{\mathrm{ab}}$ & $1386.67^{a b}$ & $1280.0^{\mathrm{b}}$ & $1280.0^{\mathrm{b}}$ & $1503.33^{a}$ & $1276.67^{b}$ & 66.58 \\
\hline Total weight gain $(\mathrm{g})$ & $703.33^{a b}$ & $716.67^{a b}$ & $723.33^{\mathrm{ab}}$ & $766.67^{\mathrm{ab}}$ & $620.0^{\mathrm{b}}$ & $620.0^{\mathrm{b}}$ & $783.33^{a}$ & $656.67^{b}$ & 66.38 \\
\hline Total feed intake (g) & $1356.67^{\mathrm{ab}}$ & $1356.67^{\mathrm{ab}}$ & $1383.33^{a}$ & $1453.33^{\mathrm{ab}}$ & $1280.0^{\mathrm{ab}}$ & $1280.0^{\mathrm{ab}}$ & $1273.0^{\mathrm{ab}}$ & $1276.0^{\mathrm{b}}$ & 66.58 \\
\hline Feed conversion ratio & $1.93^{\mathrm{ab}}$ & $1.89^{\mathrm{b}}$ & $1.91^{\mathrm{b}}$ & $1.89^{\mathrm{b}}$ & $2.06^{\mathrm{a}}$ & $2.06^{\mathrm{a}}$ & $1.62^{\mathrm{c}}$ & $1.94^{\mathrm{ab}}$ & 0.06 \\
\hline
\end{tabular}

${ }^{a b c}$ Mean on the same row having different superscripts are significantly different $(P<0.05)$.

$(\mathrm{P}<0.05)$ value of 50.00 um in birds fed 500 ppm levels of lactose inclusion. The trend observed in width (apical) of villus showed that birds fed $0 \mathrm{ppm}$ lactose, $250 \mathrm{ppm}$ mannose and 500 ppm mannose recorded higher values, and those on 500 ppm lactose had least $(P<0.05)$ values. The report of intestinal morphology of the broiler finisher in the present study supported the works of Savage et al. (1996) and lji et al. (2001) that MOS influenced the 
Table 4. Interaction effect of prebiotic sources and prebiotic levels of inclusion on gut morphology ( $\mu \mathrm{m})$ of finishing broilers.

\begin{tabular}{|c|c|c|c|c|c|c|c|c|c|}
\hline \multirow{2}{*}{ Parameters } & \multicolumn{4}{|c|}{ Lactose } & \multicolumn{4}{|c|}{ Mannose } & \multirow{2}{*}{ SEM } \\
\hline & 0 ppm & 250 ppm & 500 ppm & 75 0ppm & 0 ppm & 250 ppm & 500 ppm & 750 ppm & \\
\hline Villi height & $538.30^{d}$ & $550.00^{d}$ & $750.00^{d}$ & $922.70^{\mathrm{cd}}$ & $975.00^{\mathrm{cd}}$ & $1372.30^{\mathrm{bc}}$ & $2250.00^{a}$ & $1800.00^{\mathrm{ab}}$ & 129.44 \\
\hline Lamina propia depth & $725.00^{a}$ & $512.67^{\mathrm{bc}}$ & $437.67^{\text {cde }}$ & $462.67^{\text {cde }}$ & $262.67^{f}$ & $562.67^{b}$ & $337.67^{\text {ef }}$ & $375.00^{\text {def }}$ & 30.21 \\
\hline Basal width & $325.00^{\mathrm{bc}}$ & $427.70^{\mathrm{b}}$ & $100 . \mathrm{cd}$ & $425.00^{b}$ & $127.70^{\mathrm{cd}}$ & $162.70^{\mathrm{cd}}$ & $750.00^{a}$ & $100.00^{\mathrm{cd}}$ & 59.59 \\
\hline Apical width & $125.00^{a}$ & $75.00^{c}$ & $100.00^{\mathrm{b}}$ & $75.00^{\mathrm{a}}$ & $57.67^{d}$ & $112.67^{a}$ & $125.00^{a}$ & $60.00^{\mathrm{cd}}$ & 8.35 \\
\hline
\end{tabular}

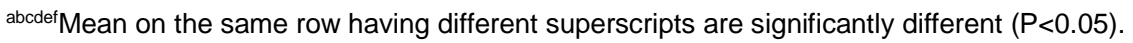

physical properties of the epithelial lining by increasing the number of globlet cells with an inclusion level of mannose.

\section{Conclusion}

Higher final live weight, weight gain, improved FCR and villi height recorded for broilers fed 500 ppm mannan oligossacharides (MOS) suggested the superiority of MOS over lactose (LOS) in supporting growth and gut morphology of broiler chickens.

\section{CONFLICT OF INTEREST}

The authors declare that they have no conflict of interest.

\section{REFERENCES}

Anak, G. K., Gillespire, I. A., O'Brien, S. J., Ward, L. R., \& Smith, H. R. (2000). Foodborne general outbreaks of Salmonella Enteritidis phage type 4 infection, England and Wales, 1992- 2002. Where are the risks? Epidemiol Infect, 133, 795- 801.

AOAC. (2000). Official method of analysis, $15^{\text {th }}$ ed. Association of Official Analytical Chemists.

Blake, J. P., Hess, J. B., Maklin, K. S., Biligili, S. F., Sefton, A. E., \& Kocher, A. (2006). Mannan Oligosaccharide Supplementation of wheat based diets for broilers. Poultry Sci. J., 62, 342.

Casewell, M., Friis, C., Marco, E., McMullin, P., \& Phillips, I. (2003). The European ban on growth-promoting antibiotics and emerging consequences for human and animal health. $J$. Antimicrob. Chemother. 46, 1052.

Cervantes, H. (2005). Assessing the results of the European Union ban of antibiotics feed additives. In: Proceedings, Thirty Second Annual Carolina poultry nutrition conference, North Carolina, October, 26-27.

Dibner, J. J., \& Richards. J. D. (2005). Antibiotic growth promoters in agriculture: history and mode of action. Poult. Sci., 84, 634-643.

Duncan, D. B. (1995). Multiple Range and Multiple F-test. Biometric, 11(1), 24.
Ferket, P. R. (2003). Managing gut health in a world without antibiotics. In: Proceedings from Alltech's $17^{\text {th }}$ European Middle Eastern and African Lecture Tour. Alltech England, UK.

Fons, A. G, \& Tuomo Karjalainen, M. (2000). Mechanisms of colonisation and colonisation resistance of the digestive tract Part 2: Bacteria/bacteria interactions. Microbial Ecology in Health and Disease, 12(2), 240-246.

Gustafon, R. H., \& Bowen, R. E. (1997). Antibiotic use in animal agriculture. J. App. Micro., 83, 531-541.

Hooge, D. (2004). Meta-analysis of broiler chicken pen trials evaluating dietary mannan oligosaccharide, 1993-2003. Int. J. Poult. Sci., 3, 163-174.

Iji, P. A., Saki, A. A., \& Tivey, D. R. (2001). Intestinal structure and function of broiler chickens on diets supplemented with a mannan oligosaccharide. J. Sci. Food Agric., 81, 1186-92.

Konstantinov, S. R., Zhu, W. Y., Williams, B. A., Tamminga, S., Vos, W. M., \& Akkermans, A. D. L. (2003). Effects of fermentable carbohydrates on piglet faecal bacterial communities as revealed by denaturing gradient gel electrophoresis analysis of $16 \mathrm{~S}$ ribosomal DNA. FEMS Microbiol. Ecol., 43, 225-235.

National Research Council (NRC). (1994). Nutritional requirements of poultry. 9th Revised Edition. National Academy Press, Washington, DC

Nayak, R., \& Kenny, P. B. (2002). Screening of Salmonella isolates from a turkey production facility for antibiotic resistance. Poult. Sci., 81, 1496-1500.

Patterson, J. A., \& Burkholder, K. (2003). Application of prebiotics and probiotics in poultry production. Poult. Sci., 82, 627-631.

Rastall, R. A., Gibson, G. R., Gill, H. S., Guarner, F., Klaenhammer, T. R., Pot, B., Reid, G., Rowland, I. R., \& Sanders, M. E. (2005). Modulation of the microbial ecology of the human colon by probiotics, prebiotics and synbiotics to enhance human health: an overview of enabling science and potential applications. FEMS Microbiol. Ecol., 52, 145-152.

SAS. (1999). Statistical Analysis Software, Version 8, SAS Institute, Cary. NC.

Savage, T. F.,Cotter, P. F., \& Zakrzewska, E. I. (1996). The effect of feeding a mannan oligosaccharide on immunoglobulins, plasma $\lg \mathrm{A}$, and bile $\lg \mathrm{A}$ of Wrolstad MW male turkeys. Poult. Sci., 75(Suppl. 1), S129.

Truscott, R. B., \& Alsheikhly, F. (1997). The production and treatment of necrotic enteritis in broilers. Am. J. Vet. Res., 38, 857-861. 